\title{
Price Transmission in the Antebellum Slave Markets: A Time Series Analysis
}

\author{
Bradley T. Ewing, James E. Payne, Mark Thornton, and \\ Mark A. Yanochik*
}

\begin{abstract}
This paper examines how price shocks in antebellum slave markets were transmitted to surrounding slave markets. A newly developed time series econometric technique is utilized to estimate the transmission of price shocks among slave markets and to investigate the univariate and multivariate time series properties of slave prices in four geographically dispersed markets. The results suggest that these markets were linked and that information flowed from one market to another. The westward, expansionary path of the slave economy is confirmed by a greater magnitude of impact from price shocks in markets to the east of the location in which the shock originated and a greater degree of unidirectional price linkage between slave markets. This new empirical evidence describes the connectedness of regional slave markets in the antebellum South and demonstrates that the overall market was effective. The paper also provides a foundation for addressing additional issues such as slave price convergence.
\end{abstract}

"Relatively little work has been done on the integration of geographically distinct labor markets before the Civil War" Robert Margo (2000, p. 97).

\section{INTRODUCTION}

Economic historians have questioned the efficiency, rationality, and morality of antebellum labor markets. Robert Fogel (1989) has suggested that the antebellum labor force faced a "hidden depression" while Kiesling and Margo (1997) found a great expansion in private charity. These results imply difficult economic times for the labor force and support the notion of an "antebellum puzzle," in which evidence of declining levels of nutrition and increased morbidity and mortality occurred during a period of rapid economic expansion. ${ }^{1}$ Evidence of persistent wage gaps between regions and sectors suggests that labor markets did not adjust quickly and contributed to suboptimal levels of output and delays in economic growth. One explanation for these gaps suggested by Lebergott (1964) rests on the notion of imperfect information. He noted "occasional marked differentials in wage rates between markets (are) largely explicable in terms of the simple

"Department of Economics, Baylor University, Waco, TX; Department of Economics, Illinois State University, Normal, IL; Ludwig von Mises Institute, Auburn, AL; and Department of Finance and Economics, Georgia Southern University, Statesboro, GA.

1See, for example, Margo and Steckel (1983), Komlos (1987), and Pope (1992) for evidence of an antebellum puzzle. For the resolution to the puzzle, see Thornton (1995), Komlos (1996) and Gallman (1996). 
imperfections of the labor market of the time. ${ }^{2}$ With the discovery of new data and the advent of new techniques, many of the inconsistencies, puzzles, and anomalies of antebellum free labor markets have been solved or are at least moving towards solutions.

The functioning of the antebellum slave market has also been questioned. Economists from Phillips (1918) to Greenwald and Glasspiegel (1983) have argued that slaves were persistently overpriced. Wright (1973) has attempted a defense of Phillips' (1918) claim, while Pritchett and Chamberlain (1993) have challenged Greenwald and Glasspiegel's (1983) finding of "lemons" in the New Orleans slave market. Economic historians have also questioned the traditional view of the interstate slave trade as a necessary institution for the economic viability of slavery and prosperity of the South. Miller (1965) found that the slave trade was not necessary for the survival of slavery, did not increase westward migration, and provided little or no benefits for market participants. Passell and Wright (1972) and Kotlikoff and Pinera (1977) have also argued that the interstate slave trade was not in the interests of the East because of its impact on output prices and capital values, but Schmitz and Schaefer (1981) suggest that the slave trade may not have been a paradox of the economic interests of slave exporters from the East.

Was the interstate slave trade rational? Was it efficient? Were slaves moved west in insufficient or excessive amounts, which thus retarded economic growth? Many issues of debate still remain regarding the interstate movement of slaves. ${ }^{3}$ One issue in particular, the degree to which regional slave markets were connected or integrated, has gone largely uninvestigated as suggested in Margo's (2000, p. 97) lament that "relatively little work has been done on the integration of geographically distinct labor markets before the Civil War." Eugene Genovese claimed that the system met "the standards of rationality developed to study the capitalist marketplace" to economist Gavin Wright, who charged that "there is little hope for conclusive establishment of...substantial deviation from profitmaximizing behavior;" the vast, morally wrenching literature on the economics of slavery is based on the assumption of a well-functioning regional slave market. ${ }^{4}$ Even those who argue against the rationality of slave markets have based their findings on the assumption of markets with equilibrating tendencies. ${ }^{5}$

We examine the behavior of slave markets by observing the pattern and degree of interconnectedness of slave markets across the antebellum South. The objective is to determine the relative efficiency of price information transmission among some of the principal antebellum slave markets by measuring the magnitude of unanticipated price shocks in one slave market and their transmission to the other slave markets over the period 1800-1860. A vector autoregression model

\footnotetext{
${ }^{2}$ As quoted in Margo (2000, p. 98). On the basis of new evidence, Margo (2000) judged antebellum labor markets to have been "effective" in the face of rapid and multifaceted economic change; however, many gaps and their full explanations have yet to be worked out.

${ }^{3}$ For example, Fogel (1989, p. 67) notes that cliometricians have yet to establish if most slaves were sold through traders or transported en masse by their owners to new plantations in the West.

${ }^{4}$ Genovese as quoted in Wright (1973, p. 460).

5 See, for example, Greenwald and Glasspiegel (1983, pp. 479-481), who suggest that their results undermine estimates of rates of return on slaves and much of the previous literature on the economics and "nature" of slavery.
} 
is estimated to examine the dynamic relationships among these slave markets using the newly developed technique of generalized impulse response analysis. The finding of price linkages between markets provides new empirical evidence on the effectiveness of the interstate slave market and enhances our understanding of the development of the antebellum economy. ${ }^{6}$

\section{THE ANTEBELLUM MARKET FOR SLAVES}

Prior to the prohibition on the importation of slaves, the slave trade was primarily one of importation into the primary seaports of the South and diffusion upriver and into the surrounding area. ${ }^{7}$ Phillips (1918) concluded that the interstate slave trade was insignificant before 1815 , but with the closure of the Atlantic slave trade and economic expansion into the central South (Alabama and Mississippi) and Southwest (Louisiana and Texas) the demand for the interstate traffic in slaves increased. There were no barriers or artificial costs to the interstate slave trade and, unlike other slave societies, there were no restrictions on the sale of slaves. ${ }^{8}$ Several authors have noted that many slave owners exhibited strong moral restraint against the breakup of slave families and that there was strong social condemnation against involvement in the interstate trafficking in slaves. However, these sentiments could do little to prevent the establishment of an interstate traffic in slaves. First, owners themselves moved westward, accounting for perhaps one-half of the interstate movement of slaves. ${ }^{9}$ Second, a large percentage of the turnover in slave ownership occurred at the death or bankruptcy of the owner and was therefore largely beyond the owner's control. Third, while some owners may have been willing to sacrifice economic rewards to maintain plantation stability, there were certainly others who did not care to or had the luxury of foregoing the profit maximand. Therefore, the antebellum market for slaves had few barriers to slave trading other than normal transport and transaction costs.

The slave-based plantation system expanded westward throughout the antebellum period, with resources flowing from the tidewater regions in the East towards the plains of the Southwest, and this movement played a distinct role in the intertemporal functioning of regional slave markets. The traditional explanation for this westward migration was based on three economic forces. First, the staple crops, such as cotton and tobacco, grown on eastern plantations were very taxing on the soil and required fertilization, crop rotation, and field rotation to maintain productivity. Second, land in the states of Alabama, Mississippi, Louisiana, Texas, and Arkansas was more productive than in the East and was often less susceptible to drought and depletion. Even if cotton and tobacco had not depleted the soil of nutrients, it is still probable that a westward expansion of

\footnotetext{
${ }^{6}$ Specifically, these results may lead to improvements in our understanding in such areas as migration patterns, economic growth, and interregional wage gaps.

7There was also a flow of slaves from north to south as northern states abolished slavery.

8Stroud (1856, pp. 82-83) notes that, unlike other slave societies, there were no restrictions on the separation of husband from wife or of children from parent via sale, except in the state of Louisiana. Many states did close their borders to slave dealers for short periods of time, but such restrictions were ineffectual, unenforced, did not limit slave owners from moving their own slaves, and were quickly repealed.

${ }^{9}$ The estimates for owner-directed interstate slave movements have been widely divergent. For a discussion of the literature, see Tadman $(1979,1989)$.
} 
the slave economy would have taken place because of the greater productivity of western lands. Third, improvements in transportation technology, particularly steamships and railroads, opened up an even greater portion of the Southwest to plantation agriculture and lowered the cost of exploiting western land.

In addition to slave owners moving their own slaves and capital to the West, the westward movement of resources was facilitated by markets that were established to organize the buying and selling of slaves. ${ }^{10}$ These markets consisted of individual dealers who purchased slaves and moved them in large groups, and formal auction houses that had originally been organized to facilitate the intraregional slave trade. We examine the four major slave markets (Richmond, Charleston, middle Georgia, and New Orleans) that functioned throughout the antebellum period to study price linkages between markets (Bancroft 1931). ${ }^{11}$

Richmond was a primary slave market in the mid-Atlantic region and the central market for Maryland, Delaware, Virginia, and northern North Carolina. Slaves were the crucial supply of labor for the tobacco plantations of the upper South, but the economic viability of slave labor on tobacco plantations diminished throughout the antebellum period. Soil depletion was one reason for this result. Another was the increased likelihood of successful escape from the plantations of the upper South compared to the lower South. ${ }^{12}$ Finally, the relative profitability of cotton raised the opportunity cost of slaves in tobacco-growing regions. Therefore, an important function of the Richmond market was to facilitate the movement of slaves from this subregion to other subregions of the South. ${ }^{13}$

The relative profitability of plantation agriculture also declined in South Carolina over the antebellum period. Heavy cultivation of cotton and other staples reduced the productivity of South Carolina's soil by the late antebellum period (Gray 1941, p. 445; Phillips 1918, pp. 332-336). Like Richmond, Charleston became a major slave-trading center for its subregion, which included southern North Carolina, Georgia, and South Carolina, and became an exporter of slaves during the antebellum period (Bancroft 1931, p. 175).

The middle Georgia slave market was centered on Macon and influenced a wide area that included large parts of Georgia, Alabama, and Florida. It was a dynamic "mixed" market in that it was both an importer and exporter of slaves. The state of Georgia was divided geographically by the middle Georgia market: to the south and west plantation agriculture remained profitable throughout the

\footnotetext{
10The following discussion is based on Tadman (1989, pp. 47-108) and the other major histories of antebellum slave markets. The movement of slaves from the Border States to the Southwest was augmented by population growth. According to Sutch (1975, pp. 174-198) the anecdotal, indirect, and circumstantial evidence all points to conscious slave breeding on the part of plantation owners in the eastern and Border States. See Collins (1904, pp. 68-83) for a different view. Additionally, Pritchett (2001) discusses estimates of owner-directed slave movements, while Russell (1993) provides more information on the sale of slaves.

${ }^{11}$ There were other major slave markets that developed as the antebellum economy moved west, such as Natchez, Mississippi, and Memphis, Tennessee, but these were not active and organized throughout the antebellum period.

12 Yet another sign of the diminished economic viability of slave labor on tobacco plantations was the transition in the upper South to a more diversified economy that employed large numbers of slaves outside of tobacco cultivation. Related research by Yanochik, Ewing, and Thornton (2001) provides evidence as to how state-level changes in slave codes affected slave prices.

13 On the importance of slave breeding and for a description of the Richmond market see Bancroft (1931, chs. 3-4). Also, see Stampp (1956, pp. 260-263) on the regional nature of the Richmond market.
} 
antebellum period and to the north and east plantation agriculture experienced a relative decline in the late antebellum period. ${ }^{14}$ The middle Georgia market therefore served as a conduit of slaves from the upper South to the lower South and Southwest (Bancroft 1931, p. 400).

New Orleans was the largest and most complex slave market in the antebellum South. With the exception of periodic panics and depressions that impacted the whole South, plantation agriculture remained economically viable in Louisiana and the demand for slaves remained strong throughout the entire antebellum period. In addition to the demands of the cotton economy, the New Orleans slave market was the primary source of slave labor for the Louisiana sugar industry. ${ }^{15}$ Sugar production was the most labor-intensive of all the staple crops grown in the South and this greatly stimulated the demand for a specific type of slave, the "prime males," in the sugar-growing region of Louisiana. ${ }^{16}$ The asset specificity of slaves required for the Louisiana labor market therefore placed great demands on slave traders in New Orleans; thus, their ability to gather and assimilate information about distant markets as well as individual slaves was very important.

In order to test the degree to which these markets were connected we use data on the price of slaves presented by Phillips (1918, pp. 370-371). He constructed a time series of slave prices in the four locations, Richmond, Charleston, middle Georgia, and New Orleans, that had reliable data over the entire period of 18001860. These price series were computed from a rather large array of travelers' notes, newspaper items, plantation appraisals, and bills of sale. ${ }^{17}$ Phillips' (1918) slave price series included only "prime male field hands" (approximately ages 18 to 30 years) because he felt that this market grade of slave was the most homogeneous and therefore the easiest to accurately estimate. Phillips further justified the use of a price series containing only prime males because the prices of all other categories of slaves could be thought of as a percentage of the price of the prime male field hand; therefore, the calculated series would serve to illustrate the trend in prices of all grades of slaves (Phillips 1918, pp. 368-370). ${ }^{18}$

Phillips' (1918) analysis of American slavery has been subject to a barrage of criticism, but his slave price data is generally considered reliable. ${ }^{19}$ For example, Fogel and Engerman (1974, pp. 176-177) have suggested that the Phillips (1918) slave price series may contain an upward bias, but that it is unbiased in showing year-to-year trends in slave prices and therefore its use is appropriate for

\footnotetext{
${ }^{14}$ Because of the dichotomous nature of slave markets in Georgia, there very likely occurred more speculation in slaves than in other states. See Flanders (1967, pp. 190-192).

15It is instructive to point out the importance of sugar production to Louisiana's slave economy. In 1859-1860, when Louisiana's cotton economy reached its zenith with a market value estimated at \$39.31million, the sugar crop was valued at nearly one-half this amount (estimated at \$18.19 million). See Greene (1972, pp. 195-196).

16The New Orleans slave market imported 60 percent male slaves. It has been estimated that males made up 68 percent of slaves working in the Louisiana sugar district. See Tadman (1989, p. 68).

17While there is some inconsistency between prices in these different categories, there is consistency in their use over the time series.

${ }^{18}$ See Evans $(1959$, pp. 22-26; 1961; 1962) for a discussion on the use of Phillips' $(1918)$ data and for a discussion of Phillips' (1918) data see Evans (1959, pp. 22-26; 1962).

19Wright (1973) concludes that, while Phillips work has been exposed to numerous critiques, in the final analysis it holds up very well.
} 
analyzing the interconnectedness of slave markets using time series methods. The first and second columns of Table 1 present the means and standard deviations of the natural logarithm of the series. Because of the events that drove the antebellum slave economy westward, we expect to find that these slave markets, although geographically dispersed, were economically linked. In the remainder of the paper, we attempt to measure both the magnitude and persistence of how shocks to slave prices in one market were transmitted to the other markets and to analyze those results. We begin with a determination of the time series properties of the data.

TABLE 1

Properties of the Slave Price Series and Stationarity Test Results

\begin{tabular}{lcccc}
\hline & Mean & Std. Dev. & TB & $\hat{\mathrm{t}}_{\alpha}$ \\
\hline Georgia (LNGA) & 6.6744 & 0.3408 & 1838 & -6.4342 \\
New Orleans (LNNO) & 6.7862 & 0.3129 & 1838 & -7.3879 \\
Charleston (LNCH) & 6.4885 & 0.2733 & 1838 & -5.4466 \\
Virginia (LNVA) & 6.3743 & 0.3493 & 1838 & -5.2182 \\
\hline
\end{tabular}

Notes: TB is the endogenously determined break point date. $\hat{t}_{\alpha}$ is the test statistic under consideration. The truncation lag length $k$ was determined to be one $(k=1)$. If $\hat{t}_{\alpha}$ is greater than the critical value, then the null hypothesis of an integrated process (unit root) is rejected. The $1 \%(5 \%)$ critical value from Perron (1989) with $\lambda=T B / T=.60$ is $-4.88(-4.24)$. The $1 \%(5 \%)$ critical value from Zivot and Andrews (1992) is -5.57 (-5.08).

\section{STRUCTURAL CHANGE AND THE UNIVARIATE TIME SERIES PROPERTIES OF SLAVE PRICES}

It is possible that a structural change occurred in the slave price data between the years 1830 and 1840 coinciding with the introduction of the railroad system in the South. The number of miles of constructed railways in the southern states in 1830 was zero, but by 1840 railroads were operating in each of the slave market locations considered in this paper (Taylor 1962, p. 79). Some of the cities that represent the markets we examine (e.g., Charleston) started earlier than others building railroads, but by 1840 each city had important railroads. These railroads reduced shipping time and costs and thereby increased trade and communication while opening up new market areas. Railroad construction also increased the demand for labor, and in particular, slave labor. According to Taylor (1962, p. 292), "practically everywhere (slaves) were the chief source of common labor: as construction hands on... railroads. ${ }^{\prime 20}$ This meant that railroads would possibly influence slave prices as plantation slave owners often subcontracted slaves to work on the construction of railways.

Our analysis begins with stationarity tests to determine the univariate properties of the slave market price series. Information about the underlying datagenerating process of time series has implications for the specification of the vector autoregression (VAR) that follows. In light of the fact that the introduction of 20Many sources, including Phillips (1918), confirm that slaves were an important source of labor for the construction of railroads. 
the railroad system may be a possible source of a break point and that we do not know a priori the precise date, we treat the selection of the break point as the outcome of an estimation procedure (i.e., as endogenously determined). We follow Perron (1994) to test the null hypothesis of an integrated process allowing for a possible change in the level and the trend.

The third and fourth columns of Table 1 present the results of the stationarity tests allowing for the possibility of a structural break occurring between 1830 and $1840 .{ }^{21}$ We find LNGA, LNNO, LNCH, and LNVA to be stationary around a breaking trend function with the endogenous break point determined in each case to be $1838 .{ }^{22}$ It is interesting to note that in each case the estimated coefficient on the trend change variable (not reported) was positive and significant at less than the $\mathrm{p}=.01$ level. This is consistent with the notion that the trend in prices increased after the introduction of the railroad, implying that the average growth rate in prices was higher after the break.

\section{AN EMPIRICAL FRAMEWORK FOR EXAMINING PRICE LINKAGES AMONG SLAVE MARKETS}

The central purpose of this paper is to examine how shocks in one slave market were transmitted to other slave markets in order to determine how slave markets were integrated. The VAR framework of Sims (1980) enables the dynamic relationships among time series variables to be examined using impulse response functions. However, the VAR methodology has been criticized for what is referred to as the "orthogonality assumption." The results from these traditional impulse responses may differ considerably depending on the ordering of the variables in the VAR (Lutkenpohl 1991). The generalized impulse response function, recently introduced by Pesaran and Shin (1998) and Koop, Pesaran, and Potter (1996), circumvents this shortcoming and is invariant to the ordering of the variables. Unlike the traditional method, this new technique does not impose the constraint that the underlying shocks to the VAR model are orthogonalized before impulse responses are computed.

Here, we briefly summarize the generalized impulse response analysis as it applies to the VAR model we estimate. The ensuing discussion follows closely that of Pesaran and Pesaran (1997). An impulse response function traces out the effect of shocks at time $t$ on the expected future values of the variables in the system. Two types of impulse response functions can be computed from the VAR: the traditional orthogonalized impulse response function (Sims 1980) and the recently developed generalized impulse response function of Pesaran and Shin (1998) and

${ }^{21}$ The findings of these unit root tests are consistent with the findings of Nelson and Plosser (1982), who concluded that most macroeconomic time series are trend stationary processes. Moreover, the price series behave very similarly to Hatanaka's (1996) description of pre-WWII annual macroeconomic data. Thus, we expect that the Phillips (1918) data will stand up to modern statistical tests and provide meaningful results.

22Of course, it is possible that other events may also have contributed to the structural change found to occur at this time (e.g., the Panic of 1837). We offer the railroad story as one motivation for the need to formally conduct a test of structural change. Regardless of the precise cause of a break, a proper time series analysis requires that this be taken into account when constructing the empirical model to examine price linkages among various slave markets. 
Koop, Pesaran, and Potter (1996). To facilitate our discussion of the impulse response analysis, we rewrite the VAR in its infinite moving average representation: ${ }^{23}$

$$
s_{t}=\sum_{j=0}^{\infty} A_{j} u_{t-j}
$$

where $s_{t}$ is an $m \times 1$ vector of the variables under investigation and $A_{j}=\Phi_{1} A_{j-1}+$ $\Phi_{2} A_{j-2}+\ldots+\Phi_{p} A_{j-p}, j=1,2, \ldots$, with $A_{0}=I_{m}$ and $A_{j}=0$ for $j<0 .{ }^{24}$

Let us denote the generalized impulse response function $(G)$ for a shock to the entire system, $u_{t}^{0}$, as: ${ }^{25}$

$$
G_{s}\left(N, u_{t}^{0}, \Omega_{t-1}^{0}\right)=E\left(s_{t+N} \mid u_{t}=u_{t}^{0}, \Omega_{t-1}^{0}\right)-E\left(s_{t+N} \mid \Omega_{t-1}^{0}\right),
$$

where the history of the process up to period $t-1$ is known and denoted by the information set $\Omega_{\mathrm{t}-1}^{0}$. Assume $u_{\mathrm{t}} \sim \mathrm{N}(0, \Sigma)$, and $\mathrm{E}\left(\mathrm{u}_{\mathrm{t}} \mid \mathrm{u}_{\mathrm{jt}}=\delta_{\mathrm{j}}\right)=\left(\sigma_{1 \mathrm{j},}, \sigma_{2 j}, \ldots, \sigma_{\mathrm{m} j}\right)^{\prime} \sigma_{\mathrm{j}}^{-1} \delta_{\mathrm{j}}$, where $\delta_{j}=\left(\sigma_{j i j}\right)^{-1 / 2}$ denotes a one standard error shock. Further, $e_{i}$ is $m \times 1$, with the ith element equal to one and all other elements equal to zero. The generalized impulse response function for a one standard deviation shock to the ith equation in the VAR model on the $\mathrm{jth}$ variable at horizon $\mathrm{N}$ is:

$$
G_{i j, N}=\left(e_{j}^{\prime} A_{N} \sum e_{i}\right) /\left(\sigma_{i i}\right)^{-1 / 2}, i, j=1,2, \ldots, m \text {. }
$$

The generalized impulse responses are invariant to the reordering of the variables in the VAR. Pesaran and Shin (1998) caution the researcher using orthogonalized impulse responses since there is typically no clear guidance as to which of many possible parameterizations to employ. "[T]he generalized impulse responses are unique and fully take account of the historical patterns of correlations observed amongst the different shocks" (Pesaran and Shin 1998, p. 20). ${ }^{26}$

The VAR we estimate contains four endogenous variables corresponding to the natural logarithms of the slave price series from Georgia (LNGA), New Orleans (LNNO), Charleston (LNCH), and Virginia (LNVA), and a constant term. Additionally, we control for the break date of 1838 since the variables were determined to be trend stationary around a breaking trend function. It was determined via Akaike's information criterion, Schwartz Bayesian criterion, an adjusted-forsmall-sample-size likelihood ratio statistic, ${ }^{27}$ and examination of the residuals that the optimal order of the VAR was two (i.e., $\operatorname{VAR}(p)$ with $p=2)$. The single equation results from the VAR system were then examined for appropriateness. Each of the single equations in the VAR model was free of serial correlation via the Lagrange multiplier (LM) test; additionally, none of these equations exhibited any

${ }^{23}$ Note that the model can be extended to accommodate exogenous variables without loss of generality.

${ }^{24}$ The traditional orthogonalized impulse response employs a Cholesky decomposition of the positive definite $m \times m$ covariance matrix, $\Sigma$, of the shocks $\left(u_{t}\right)$. For a description of the Cholesky decomposition see Mills (1999). The generalized version does not impose this restriction.

25In the interest of brevity we do not discuss the orthogonalized impulse response function as its use is widespread and its derivation is well known (see Mills 1999).

${ }^{26}$ The generalized and orthogonalized impulse responses coincide only for the case where the covariance matrix is diagonal.

${ }^{27}$ The degrees of freedom adjusted likelihood ratio statistic is given by $L R^{*}=(n-q-2-m P) \times L R$, where $L R$ is the standard likelihood ratio statistic, $\mathrm{p}=0,1,2, \ldots \mathrm{P}-1$, and $\mathrm{P}$ is the maximum order for the VAR. 
evidence of autoregressive conditional heteroscedasticity, or ARCH effects. The adjusted $R^{2}$ s ranged from .94 to $.97 .^{28}$

Panels A-D of Figure 1 present the results of the generalized impulse response functions for the four slave market price series to shocks in LNGA, LNNO, LNCH, and LNVA, respectively. The graphs trace out the response of the particular price series for a one standard error (positive) shock to a price series and are invariant to the ordering. The responses are plotted out for fifteen periods and are generated from the VAR model described above.

\section{FIGURE 1}

Panel A-Generalized Impulse Responses to One SE Shock in the Equation for LNGA

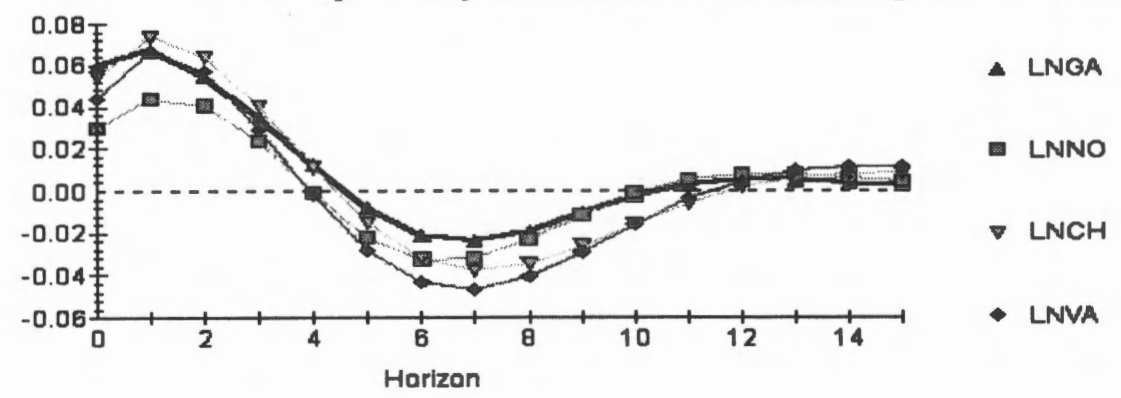

Panel B-Generalized Impulse Responses to One SE Shock in the Equation for LNNO

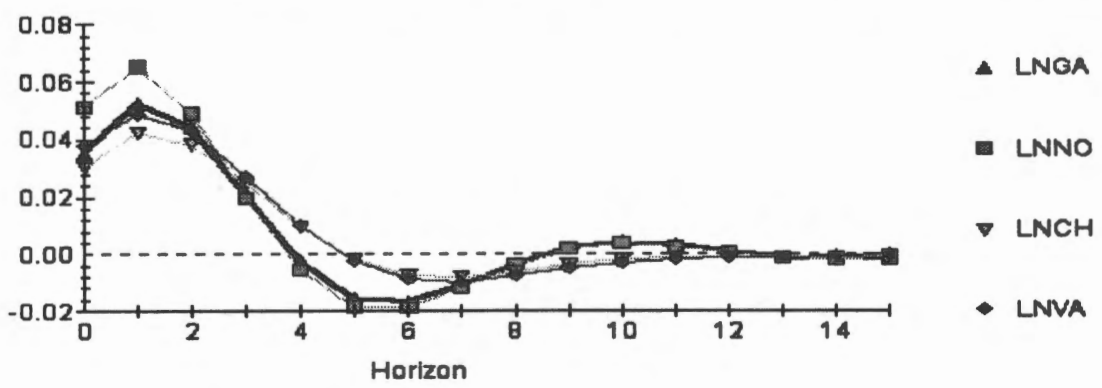

Panel C-Generalized Impulse Responses to One SE Shock in the Equation for $\mathrm{LNCH}$

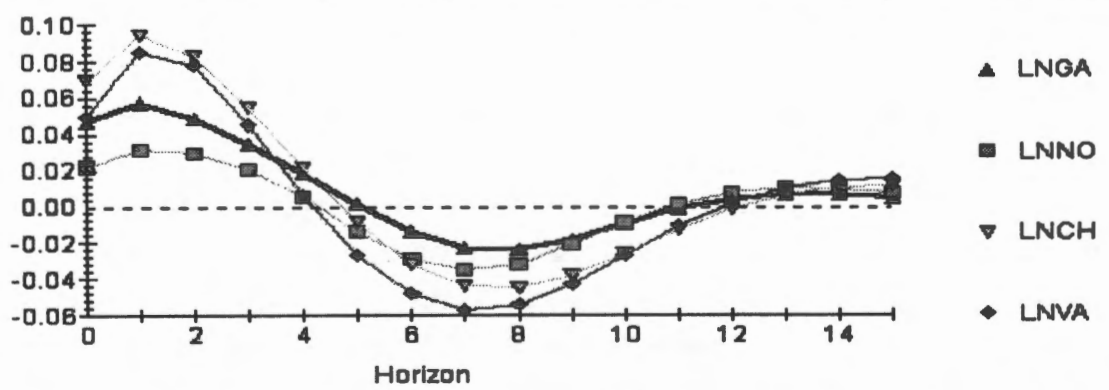

${ }^{28}$ Overall, we could not reject the hypothesis that the residuals were white noise process. This is an important conclusion since if one price series was simply a linear transformation of another, as implied by Fogel and Engerman (1974), then the residuals would exhibit a large degree of autocorrelation. The finding of well-behaved error processes provides additional support for the usefulness of the Phillips (1918) data. 
FIGURE 1-continued

Panel D-Generalized Impulse Responses to One SE Shock in the Equation for LNVA

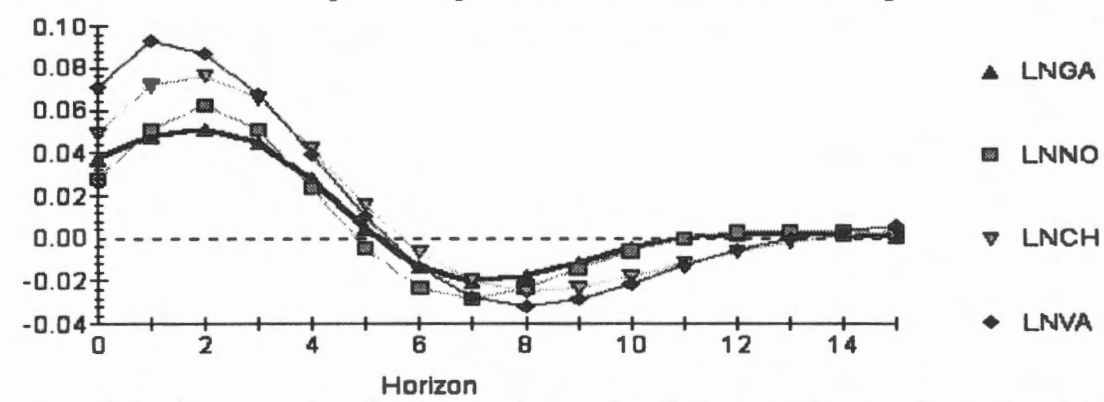

Panel A shows what happens in each of the markets when there is a one standard error shock to the equation for Georgia slave prices. A shock to the Georgia price series has the largest effect on the Georgia market followed by the markets in Charleston, Virginia, and New Orleans, respectively. The initial impact of a Georgia shock is associated with increases in prices ranging from 3 to 6 percent from the baseline (i.e., equilibrium) prices. These initial impact effects are 6.0 percent for Georgia, 5.4 percent for Charleston, 4.4 percent for Virginia, and 3.0 percent for New Orleans. In each case, prices reach their maximum following the shock after one period and then the effect starts to die off. This happens rather quickly in the New Orleans and Virginia markets, reaching zero by period 4 before overshooting and cycling sets in. For each market, the effects of a Georgia price shock, after overshooting and cycling, are essentially eliminated by ten to eleven periods, where the cumulative effects each fell to less than 1 percent. The Georgia price shock effect would have been felt over a rather protracted period of time and had its maximum impact (in absolute value) on prices in Charleston (7.3 percent), followed by Georgia ( 6.7 percent), and Virginia ( 6.7 percent) with virtually identical values after one period and the least effect on the New Orleans price (4.4 percent).

The effects of unanticipated changes in New Orleans slave market prices are presented in Panel B. These price shocks have the largest initial impact in the New Orleans market (5.1 percent) followed by the markets in Virginia (3.8 percent), Georgia (3.5 percent), and Charleston ( 3.0 percent). The maximum effect is felt after one period and then sharply drops off for New Orleans and Georgia, hitting zero around the fourth period. The effects on Charleston and Virginia do not reach zero until period 5. The maximum effects are 6.5 percent for New Orleans, 5.2 percent for Georgia, 4.9 percent for Virginia, and 4.2 percent for Charleston. Additionally, the overshooting and cycling effects are much more pronounced for New Orleans and Georgia than for Charleston and Virginia. In each case, effects of New Orleans price shocks die off to, and remain, less than 1 percent by period 8. The New Orleans price shock effect was to create price cycles especially for the Georgia market and itself, while having a much smoother and less severe effect on the slave markets of Virginia and Charleston.

Panel C shows the effects of shocks to Charleston prices. Initial impact effects vary widely from 2.2 percent for New Orleans, to 5.0 percent for Virginia, 
to 4.7 percent for Georgia, to 6.9 percent for Charleston. The values of the maximum impact effects were obtained in period 1: New Orleans 3.1 percent, Georgia 5.7 percent, Virginia 8.5 percent, and Charleston 9.4 percent. The effect essentially died off to zero after four periods for Virginia and New Orleans, and after five periods for Charleston and Georgia, before overshooting and cycling. The Charleston price shock effect lingered on for around eleven to twelve periods.

Panel D presents the dynamical response of each of the markets to a shock to Virginia prices. As in the other three cases, the initial impact effect is strongest for the market where the shock emanated. Initial impact effects are 7.1 percent for Virginia, 4.9 percent for Charleston, 3.7 percent for Georgia, and 2.7 percent for New Orleans. The maximum effect occurs after two periods for Georgia (5.1 percent), New Orleans (6.2 percent), and Charleston ( 7.7 percent), and after one period for Virginia ( 9.3 percent). The effect reaches zero after five periods for the New Orleans and Georgia markets, and between five and six periods for the Charleston and Virginia markets, before beginning the familiar overshooting and cycling behavior. The Virginia price shock effect lasts the longest of any of those examined so far, falling to (and remaining) less than 1 percent after ten periods for the Georgia and New Orleans markets, and as long as twelve periods for the markets of Charleston and Virginia. Virginia's "own" impact response is both initially larger than "own" effects in the other markets and also lasts longer.

Overall, price shocks in the respective markets had differential effects. In particular, the initial effects of New Orleans shocks were noticeable but were not as pronounced as those of Georgia shocks, while Charleston and Virginia shocks were much more variable than either New Orleans or Georgia shocks. Ranking them by mean initial impact effect, we find Georgia and Charleston are virtually tied, followed by Virginia and then New Orleans. Ranking the markets from highest to lowest by the spread between the maximum initial impact and minimum initial impact we have Charleston, followed by Virginia, Georgia, and New Orleans. Similarly, ranking the markets by mean maximum impact effect (regardless of period) from high to low gives Virginia, Charleston, Georgia, and New Orleans. Generally speaking, we also note that shocks first died off to zero for shocks to Georgia, New Orleans, and Charleston in the range of four to five periods, and from five to six periods for Virginia. The New Orleans effects were the least persistent of all the price shocks and the effects of a shock to Virginia persisted the longest, tollowed closely by Charleston. Thus, ranking the markets in terms of persistence from greatest to least we would have Virginia, Charleston, Georgia, and New Orleans.

\section{PRICE LINKAGES IN THE SOUTHERN SLAVE MARKET}

These results establish important inferences about the antebellum slave markets, how particular markets were linked, and the relative strengths of these associations. The American slave economy followed a westward, expansionary path and, given the cost of transportation and communication, we would expect 
the magnitude of impact of price shocks to be the greatest when a market lies to the immediate east of the location in question. While this does not rule out price linkages that transmit in both directions, it does imply a greater degree of price linkage, in a unidirectional sense, between these two markets. In particular, since the degree of infrastructure would be more developed to the east of a market, we expect the price transmission, which would take the path of least resistance, to be more pronounced to the east than to the west. Thus, a shock that emanates from a market would likely exhibit a greater degree of price linkage in this direction. This is clearly illustrated in our forecasted outcomes. By and large, when a shock is introduced to a particular location, the strongest impact is felt in the slave market nearest to it in an easterly direction. For example, when a shock is simulated in the Middle Georgia slave market, the magnitude of the impact is greatest in the Charleston, followed by Richmond. To illustrate, if in a given year the demand for slaves had risen sharply in Georgia, all else equal, the price of slaves in the Charleston market would have adjusted most rapidly to this change in market data, with prices in Richmond also changing, but less rapidly. If the demand for slaves had decreased sharply in the Charleston market, all else equal, the price of slaves in the Richmond market would have adjusted downward faster than in the other markets. ${ }^{29}$

An anomaly in the New Orleans slave market appears to challenge this general pattern. When a shock is introduced to New Orleans, the greatest impact is realized in the market not closest, but farthest away in an easterly direction: Richmond. This finding is actually consistent with what was observed in the antebellum South. The New Orleans slave market was closely tied to Richmond and to other areas of the upper South. ${ }^{30}$ This Richmond-New Orleans nexus was observed during the antebellum period and is not in doubt in the current literature. The establishment of this unique trade route owes itself mainly, but not exclusively, to the development during the antebellum years of a relatively efficient coastwise shipping network as well as the movement of slaves overland (even to New Orleans via Middle Georgia or Charleston) (Tadman 1989, p. 65; Bancroft 1931, pp. 315-316). Thus, our results verify the observed link between New Orleans and Richmond.

It is also interesting to note that, although New Orleans' primary link was Richmond, this link is not as strong as the link between Middle Georgia and Charleston, or between Charleston and Richmond. This is likely because of the greater spatial distance that information about changing market conditions in New Orleans had to travel before it reached Richmond. ${ }^{31}$ The large geographical dispersion between New Orleans and Richmond meant that changes in New Orleans had to be discounted by participants in Richmond (much like a regional bill of exchange) to gain a legitimate appraisal of its accuracy.

\footnotetext{
${ }^{29}$ When the Richmond market receives a shock, the greatest impact is felt in Charleston. This is to be expected, since Charleston, although located west of Richmond, is in greater proximity to Richmond than the other markets. ${ }^{30}$ See Clark (1934) on the north-south flow of slaves to New Orleans.

31 The first intercity telegraph line was established between Washington and Baltimore in 1844 and all the major cities of the South were linked to the telegraph network by 1852 (Fogel 1989, p. 67).
} 
In addition, even though New Orleans was a principle demander of slaves from Richmond, it also relied heavily on slaves imported from other areas of the South. Since the New Orleans slave market was fed from other areas, it is reasonable to suspect that the magnitudes of impact in each market, taken individually, would be smaller than the magnitude of impact felt in a market that is the only significant supplier of slaves to a contiguous, westerly market (e.g., the impact felt in Charleston when a shock is introduced in Middle Georgia). Compare our forecasts for the two slave markets that were located in regions still dependent upon the plantation system by the late antebellum period, Middle Georgia and New Orleans. Given our thesis of westward expansion, a shock to the Middle Georgia market is felt mostly strongly in Charleston, followed by Richmond, then eventually in New Orleans. A shock to the New Orleans market is transmitted (in declining magnitude) to Richmond, Middle Georgia, then Charleston. Notice, however, that the magnitude of impact in the second- and third-most important markets, when compared to the most important market, falls proportionally less for New Orleans (from 3.8 percent for Richmond, to 3.3 percent Middle Georgia, to 3.0 percent for Charleston) than for Middle Georgia (from 5.4 percent Charleston, to 4.4 percent for Richmond, to 3.0 percent for New Orleans). This would suggest that New Orleans was the slave market (when considering a westerly, unidirectional trading pattern) that was most connected to other slave markets of the antebellum South. Considering the strength and robustness of New Orleans' economy during the late antebellum period, this premise does not seem surprising. ${ }^{32}$

The persistence of price shocks to the various markets also provides us with important information about the nature of the antebellum slave economy. Notice that when the slave markets are ranked in terms of greatest degree of persistence, we obtain the following results: Richmond, Charleston, Middle Georgia, and New Orleans. This would suggest that, for example, when a shock is introduced to Richmond, the actual market price for slaves would overshoot the equilibrium price and remain in a state of disequilibrium for the longest period of time (when compared with the other markets). Richmond was therefore the market least effective at transmitting accurate slave price information to the other markets.

As the economy of the upper South began to industrialize, significant "noise" was incorporated into the determination of slave prices. Slavery in this region was changing in an important manner. As plantation agriculture in Virginia continued oîi its path of secular decline and manufacturing and transportation became more prominent, slaves were often hired out by their owners to industrial concerns. In many instances, slaves in the upper South were given the freedom by their masters to seek work, bargain for wages, etc. ${ }^{33}$ Slaves were hired to work in a wide variety of occupations, including in factories and construction. Accordingly, the value of a slave in Richmond (especially in the late antebellum period) could not be based strictly on plantation agriculture. In addition, the 32The slave economy of Louisiana thrived because of several factors, including the cotton boom and the fact that railroads were lowering the cost of plantation agriculture. Protectionist federal policies on sugar also supported the economic boom and the value of slaves.

${ }^{33}$ See Eaton (1960) and Goldin (1976) on the importance of slave hiring in the upper South. 
industrialization of the upper South brought increasing competition from free labor. The fact that slaves now were competing with free workers for jobs would also tend to distort slave price information coming out of Richmond..$^{34}$

One parallel between all markets was that shocks to any of the markets were transmitted to each of the other markets, with effects that ranged from 2 percent to more than 8 percent. Additionally, regardless of where the shock was initiated, all markets would experience a price cycling effect that would last anywhere from four to twelve years. These results suggest that these markets were segmented in terms of geographical location and that events in one market were transmitted to other markets fairly quickly and often persisted for prolonged periods of time. That is, we find evidence of regional price cycle transmission. Based on the evidence provided here, the Virginia and Charleston markets had the most pronounced linkages to other markets, followed by Georgia, and then New Orleans. However, the conclusion that the New Orleans market had the least impact on other markets and was the least affected by other markets does not imply it was somehow inferior. Indeed, it may be argued that New Orleans operated more independently than the other markets and in this sense was strong enough to resist the influence of events happening elsewhere. This is consistent with the notion that New Orleans, because of its large size and distance from other markets, the special needs of Louisiana's plantation economy (e.g., the production of sugar), as well as its role as a regional and national trading center, was perhaps the most unique of the four markets.

\section{SUMMARY AND CONCLUSIONS}

The history of the interstate slave trade has been long established and is well known. ${ }^{35}$ Several economic, empirical, and moral issues concerning this trade have been raised and debated in literature, but the basic efficiency and rationality of the interstate trade (which is often assumed) has not been addressed. The transmission of price shocks and the degree to which the antebellum slave market was integrated is investigated here with advanced time series econometric techniques. Data from four geographically dispersed markets are used to determine the univariate and multivariate time series properties of slave prices and the results clearly show that these markets were linked and that information flowed from one market to another.

In general, our evidence is consistent with an economy following a westward, expansionary path. The magnitude of impact from price shocks is greatest when a market lies to the immediate east of the location in which the shock originated, although important anomalies were also found. The multiple-year duration of the impact from price shocks is also consistent with supply conditions such

${ }^{34}$ To a lesser degree, price information from the Charleston slave market also included significant noise. Notice that Charleston was just behind Richmond with respect to the amount of noise included in slave prices. In the latter antebellum years, the Carolinas, like Virginia, were also becoming increasingly industrialized. The Carolinas were perhaps a decade behind Virginia in this transformation, however.

35The major histories of the interstate slave trade include Collins (1904), Phillips (1918), Bancroft (1931), Stampp (1956), Evans (1961), and Tadman (1989). 
as transport time and agricultural production schedules in the short run and the time necessary to produce children and raise them to adults in the long run.

While price movements are the core element of this analysis, technology is also investigated and found to have an important impact. The development of the railroad system in the South played a large role in both the expansion and integration (i.e., connectedness) of slave markets. Railroads connected markets for slaves, inputs, and outputs. The result was both an enhanced competition between the means of transportation and an increase in the speed of communications. The development of the telegraph system progressed with the expansion of the railroad system and no doubt enhanced the flow of information. The impact of technology is empirically established here with the finding of a structural break in the time series data. Our results indicate that the speed of adjustment to price shocks increased after the introduction of interstate railroad system.

This study provides empirical support for historical notions regarding the pathways of the interstate slave trade while challenging others. In addition, it provides specific empirical content regarding such issues as the speed of market adjustment and the impact of technology. Most importantly, it addresses the question of the rationality and efficiency of the interstate slave market and finds that this regional market was integrated and effective. Furthermore, these findings provide an important foundation for the study of slave price convergence between regional markets and the related issue of wage rate convergence between subregions.

\section{REFERENCES}

Bancroft, F. Slave Trading in the Old South. Baltimore: J.H. Furst Company, 1931.

Clark, T.D. "The Slave Trade between Kentucky and the Cotton Kingdom." The Mississippi Valley Historical Review 21 (1934), 331-342.

Collins, W.H. The Domestic Slave Trade of the Southern States. Port Washington, N.Y.: Kennikat Press, Inc., 1904.

Eaton, C. "Slave Hiring in the Upper South: A Step toward Freedom." The Mississippi Valley Historical Review 46 (1960), 663-668.

Evans, R., Jr. "The Economics of American Negro Slavery, 1830-1860." Ph.D. diss., University of Chicago, 1959.

. "Some Economic Aspects of the Domestic Slave Trade, 1830-1860." Southern Economic Journal 27 (1961), 329-337.

. "The Economics of American Negro Slavery, 1830-1860." In UniversitiesNational Bureau Committee for Economic Research, Aspects of Labor Economics. Princeton, N.J.: Princeton University Press, 1962.

Flanders, R.B. Plantation Slavery in Georgia. Chapel Hill: University of North Carolina Press, 1967.

Fogel, R.W. Without Consent or Contract: The Rise and Fall of American Slavery. New York: W.W. Norton \& Company, 1989. 
Fogel, R.W., and S.L. Engerman Time On The Cross: Evidence and Methods-A Supplement. Boston: Little, Brown and Company, 1974.

Gallman, R.E. "Dietary Change in Antebellum America." Journal of Economic History 56 (1996), 193-201.

Goldin, C.D. Urban Slavery in the American South. Chicago: University of Chicago Press, 1976.

Gray, L.C. History of Agriculture in the Southern United States to 1860. New York: Peter Smith, 1941.

Greene, G.D. Finance and Economic Development in the Old South. Stanford, Calif.: Stanford University Press, 1972.

Greenwald, B.C., and R.R. Glasspiegel. "Adverse Selection in the Market for Slaves: New Orleans, 1830-1860." Quarterly Journal of Economics 98 (1983), 479-499.

Hatanaka, M. Time-Series-Based Econometrics: Unit Roots and Cointegration. New York: Oxford University Press, 1996.

Kiesling, L., and R.A. Margo. "Explaining the Rise in Antebellum Pauperism, 1850-1860: New Evidence." Quarterly Review of Economics and Finance 37 (1997), 405-417.

Komlos, J. "Anomalies in Economic History: Towards a Resolution of the 'Antebellum Puzzle'." Journal of Economic History 56 (1996), 202-214.

. "The Height and Weight of West Point Cadets: Dietary Change in Antebellum America." Journal of Economic History 47 (1987), 897-927.

Koop, G., M.H. Pesaran, and S.M. Potter. "Impulse Response Analysis in Nonlinear Multivariate Models." Journal of Econometrics 74 (1996), 119-147.

Kotlikoff, L.J., and S. Pinera. "The Old South's Stake in the Inter-Regional Movement of Slaves, 1850-1860." Journal of Economic History 37 (1977), 434-450.

Lebergott, S. Manpower in Economic Growth: The American Record since 1800. New York: McGraw-Hill Book Company, 1964.

Lutkenpohl, H. Introduction to Multiple Time Series Analysis. Berlin: SpringerVerlag, 1991.

Margo, R.A. Wages \& Labor Markets in the United States, 1820-1860. Chicago: University of Chicago Press, 2000.

Margo, R.A., and R. Steckel. "Heights of Native Born Whites during the Antebellum Period." Journal of Economic History 43 (1983), 873-895.

Miller, W.L. "A Note on the Importance of the Interstate Slave Trade of the Ante Bellum South." Journal of Political Economy 73 (1965), 181-187.

Mills, T.C. The Econometric Modeling of Financial Times Series. 2d ed. Cambridge: Cambridge University Press, 1999.

Nelson, C.R., and C.I. Plosser. "Trends and Random Walks in Macroeconomic Time Series: Some Evidence and Implications." Journal of Monetary Economics 10 (1982), 139-162.

Passell, P., and G. Wright. "The Effects of Pre-Civil War Territorial Expansion on the Price of Slaves." Journal of Political Economy 80 (1972), 1188-1202. 
Perron, P. "Trend, Unit Root and Structural Change in Macroeconomic Time Series." In B.B. Rao (ed.) Cointegration for the Applied Economist, 113-146. New York: St. Martin's Press, 1994.

. "The Great Crash, the Oil Price Shock, and the Unit Root Hypothesis." Econometrica 57 (1989), 1361-1401.

Pesaran, M.H., and B. Pesaran. Working with Microfit 4.0. Cambridge: Camfit Data LTD, 1997.

Pesaran, M.H., and Y. Shin. "Generalized Impulse Response Analysis in Linear Multivariate Models." Economics Letters 58 (1998), 17-29.

Phillips, U.B. American Negro Slavery: A Survey of the Supply, Employment and Control of Negro Labor as Determined by the Plantation Regime. New York: D. Appleton and Company, 1918.

Pope, C.L. "Adult Mortality in America before 1900: A View from Family Histories." In C. Goldin and H. Rockoff (eds.) Strategic Factors in Nineteenth Century American Economic History: A Volume to Honor Robert W. Fogel. Chicago: University of Chicago Press, 1992.

Pritchett, J.B. "Quantitative Estimates of the United States Interregional Slave Trade, 1820-1860." Journal of Economic History 61 (2001), 467-475.

Pritchett, J.B., and R.M. Chamberlain. "Selection in the Market for Slaves: New Orleans, 1830-1860." Quarterly Journal of Economics 108 (1993), 461-473.

Russell, T.D. "Sale Day in Antebellum South Carolina: Slavery, Law, Economy, and Court-Supervised Sales." Ph.D. diss. Stanford University, 1993.

Schmitz, M., and D. Schaefer. "Paradox Lost: Westward Expansion and Slave Prices before the Civil War." Journal of Economic History 41 (1981), 402-407.

Sims, C. "Macroeconomics and Reality." Econometrica 48 (1980), 1-48.

Stampp, K.M. The Peculiar Institution: Slavery in the Ante-Bellum South. New York: Alfred A. Knopf, 1956.

Stroud, G.M. A Sketch of the Laws Relating to Slavery in the Several States of the United States of America. 2d ed. Philadelphia: Henry Longstreet, 1856.

Sutch, R. "The Breeding of Slaves for Sale and the Westward Expansion of Slavery, 1850-1860." In S.L. Engerman and E.D. Genovese (eds.) Race and Slavery in the Western Hemisphere: Quantitative Studies. Princeton, N.J.: Princeton University Press, 1975.

Tadman, M. Speculators and Slaves: Masters, Traders, and Slaves in the Old South. Madison, Wis.: University of Wisconsin Press, 1989.

"Slave Trading in the Antebellum South: An Estimate of the Interregional Slave Trade." Journal of American Studies 13 (1979), 195-220.

Taylor, G.R. The Transportation Revolution, 1815-1860. New York: Holt, Rinehart, and Winston, 1962.

Thornton, M. "Alcohol Consumption and the Standard of Living in Antebellum America." Atlantic Economic Journal 23 (1995), 156.

Wade, R.C. Slavery in the Cities: The South, 1820-1860. New York: Oxford University Press, 1964. 
Wright, G. "New and Old Views on the Economics of Slavery." Journal of Economic History 33 (1973), 452-466.

Yanochik, M.A., B.T. Ewing, and M. Thornton. "A New Perspective on Antebellum Slavery: Public Policy and Slave Prices." Atlantic Economic Journal 29 (2001), 330-340.

Zivot, E., and D.W.K. Andrews. "Further Evidence on the Great Crash, the OilPrice Shock, and the Unit-Root Hypothesis." Journal of Business and Economic Statistics 10 (1992), 251-270. 